\title{
Folic acid in low birthweight infants
}

\author{
A. C. KENDALL, E. E. JONES, C. I. D. WILSON, N. K. SHINTON, and P. C. ELWOOD \\ From Coventry Hospital Group, and the M.R.C. Epidemiology Unit, Cardiff
}

\begin{abstract}
Kendall, A. C., Jones, E. E., Wilson, C. I. D., Shinton, N. K., and Elwood, P. C. (1974). Archives of Disease in Childhood, 49, 736. Folic acid in low birthweight infants. A double-blind randomized trial of $50 \mu \mathrm{g}$ folic acid or placebo given from 2 weeks to 6 months to 130 infants of birthweight less than $2.5 \mathrm{~kg}$ has been conducted. While only 62 of the babies completed the 6-month follow-up, no significant difference was found between either group in respect of changes in weight, haemoglobin, serum folate, red cell folate, or evidence of infection. It is concluded that infants in this series were receiving adequate amounts of folic acid in their normal diet and did not require supplements.
\end{abstract}

All observers are agreed that serum and red cell folate values fall to low levels in the first year of life and that the fall occurs earlier and is greater in infants of low birthweight than in mature infants (Chanarin, 1969). Folate deficiency is the commonest cause of a megaloblastic anaemia in infancy (MacIver, 1962), and premature babies tend to develop this anaemia at about 6 to 8 weeks of age, (Hoffbrand, 1970). The serum and red cell folate levels have been shown to be related to dietary folate intake (Roberts et al., 1969). Response to treatment is entirely satisfactory, but the need for prophylactic treatment of low birthweight infants is less well established. Folic acid supplements for premature babies have been advocated (Burland, Simpson, and Lord, 1971; Roberts et al., 1972), based upon comparison of small numbers of treated and untreated infants. A dose of $50 \mu \mathrm{g}$ has been recommended by the FAO/WHO Expert Group. A double-blind trial on a larger sample of premature infants has therefore been carried out.

\section{Methods}

130 singletons admitted to the Special Care Baby Unit, Coventry Maternity Hospital, and who weighed less than $2.5 \mathrm{~kg}$ at birth, were entered in the trial and given a serial number. The nature and purpose of the trial was explained to the parents and their permission obtained. The serial numbers were notified to the hospital pharmacist who had previously allocated them at random to a 'treated' or a 'control' group. From the age of 2 weeks the 'treated' group received once daily a solution containing $50 \mu \mathrm{g}$ folic acid in each dose, the 'control'

Received 15 February 1974. group received a similar volume of an inert liquid of identical appearance. The dropper bottles in which both solutions were dispensed were identified only by the infant's serial number. Only after the trial was completed did the pharmacist make known whether an infant had been receiving folic acid or the inert solution. All the infants were fed on reconstituted dried cow's milk, and semi-solids were added from the 2 nd or 3 rd month.

Each infant admitted to the trial was weighed and a specimen of blood was obtained by heel-stab. At the age of 1 month, and then at monthly intervals up to the age of 6 months, these examinations were repeated and the mother was asked if the baby had experienced any infections. On each specimen of blood the $\mathrm{Hb}$, mean corpuscular volume (MCV), and red cell and serum folate levels were measured. $\mathrm{Hb}$ and red blood cell values were obtained by a Coulter $S$ counter, serum and red blood cell folate levels were determined by an automated microbiological assay with Lactobacillus casei (Davis, Nicol, and Kelly, 1970).

Due to failure of attendance, only 62 infants completed the trial, 29 in the treated group and 33 controls. Analysis was made of the results at 2 weeks, 4 months, and 6 months.

\section{Results}

Analysis of the treated and control group showed them to be of similar birthweight and gestational ages (Table I). There were no significant differences in rate of growth between the two groups. At all ages the mean $\mathrm{Hb}$ levels were similar in the two groups (Table II). The mean MCV of $105 \mathrm{fl}$ was the same in the two groups at 2 weeks and at 4 months, but at 6 months the value in the control group was significantly higher $(P>0.05)$ than in the treated group. There was a significant negative 
TABLE I

Comparison of mean gestational age and birthweight

\begin{tabular}{c|c|c|c|c}
\hline \multirow{2}{*}{ Variable } & \multicolumn{2}{|c|}{ Treated } & \multicolumn{2}{c}{ Placebo } \\
\cline { 2 - 3 } & No. & Mean \pm SE & No. & Mean \pm SE \\
\hline $\begin{array}{c}\text { Gestational age } \\
\text { (wk) }\end{array}$ & & & & \\
Birthweight (g) & 29 & $\begin{array}{l}37 \cdot 2 \pm 0 \cdot 33 \\
2191 \pm 43 \cdot 5\end{array}$ & 32 & $36 \cdot 8 \pm 0 \cdot 34$ \\
& & & $2196 \pm 45 \cdot 4$ \\
\hline
\end{tabular}

TABLE II

Comparison of mean age, $\mathrm{Hb}$ level, mean corpuscular volume (MCV), and weight for treated and placebo groups

\begin{tabular}{l|c|c|c|c}
\hline \multirow{2}{*}{ Variable } & \multicolumn{2}{|c|}{ Treated } & \multicolumn{2}{|c}{ Placebo } \\
\cline { 5 - 5 } & No. & Mean \pm SE & No. & Mean \pm SE \\
\hline At 2 wh & & & & \\
Actual age (dy) & 29 & $14 \cdot 2 \pm 0 \cdot 39$ & 33 & $14 \cdot 1 \pm 0 \cdot 34$ \\
Hb (g/100 ml) & 29 & $17 \cdot 1 \pm 0 \cdot 39$ & 32 & $167 \pm 0 \cdot 37$ \\
MCV (fl) & 29 & $104 \cdot 9 \pm 0 \cdot 81$ & 32 & $104 \cdot 5 \pm 0 \cdot 99$ \\
Weight (g) & 28 & $2390 \pm 61$ & 32 & $2381 \pm 55$ \\
At 4 mth & & & & \\
Actual age (dy) & 24 & $116 \cdot 3 \pm 2 \cdot 32$ & 29 & $113 \cdot 9 \pm 2 \cdot 57$ \\
Hb (g/100 ml) & 21 & $12 \cdot 8 \pm 0 \cdot 29$ & 29 & $12 \cdot 6 \pm 0 \cdot 32$ \\
MCV (fl) & 21 & $80 \cdot 1 \pm 1 \cdot 03$ & 29 & $79 \cdot 7 \pm 0 \cdot 93$ \\
Weight (g) & 24 & $5613 \pm 115$ & 29 & $5660 \pm 123$ \\
At 6 mth & & & & \\
Actual age (dy) & 24 & $174 \cdot 8 \pm 2 \cdot 54$ & 27 & $173 \cdot 0 \pm 2 \cdot 44$ \\
Hb (g/100 ml) & 24 & $11 \cdot 9 \pm 0 \cdot 33$ & 26 & $12 \cdot 5 \pm 0 \cdot 32$ \\
MCV (f) & 24 & $71 \cdot 3 \pm 1 \cdot 50$ & 26 & $75 \cdot 8 \pm 1 \cdot 62$ \\
Weight) (g) & 23 & $6877 \pm 120$ & 27 & $6875 \pm 141$ \\
& & & & \\
\hline
\end{tabular}

correlation ( $P>0.05)$ between MCV and red cell folate for the combined groups.

When the treatment was begun at the age of 2 weeks, the mean serum folate level was higher in the control group than in the treated group. (Table III). The reason for this is not known but as allocation was random it must have been chance.
At 4 months and 6 months both serum and red cell folate levels were significantly higher in the treated group $(P>0.05)$. More infections were reported in the control group (21\%) than in the treated group $(8 \%)$, but the difference did not reach a level of significance (Table IV).

\section{TABLE IV}

Number of infants who developed infections and number who were treated with antibiotics during trial

\begin{tabular}{|c|c|c|c|c|}
\hline \multirow{2}{*}{ Variable } & \multicolumn{2}{|c|}{ Treated } & \multicolumn{2}{|c|}{ Placebo } \\
\hline & No. & $\%$ & No. & $\%$ \\
\hline $\begin{array}{l}\text { At } 4 \text { mth } \\
\text { Infections } \\
\text { Antibiotics } \\
\text { At } 6 \text { mth } \\
\text { Infections } \\
\text { Antibiotics }\end{array}$ & $\begin{array}{l}1 \\
1 \\
2 \\
3\end{array}$ & $\begin{array}{r}(4) \\
(4) \\
(8) \\
(13)\end{array}$ & $\begin{array}{l}2 \\
3 \\
6 \\
7\end{array}$ & $\begin{array}{l}(7) \\
(10) \\
(21) \\
(24)\end{array}$ \\
\hline
\end{tabular}

\section{Discussion}

A double-blind trial in infants has limitations due to dependence on maternal co-operation. Only a third of the babies who entered the trial could be followed up to the age of 6 months. Some of those who dropped out of the trial had died, some had developed conditions which necessitated their admission to hospital, some lived at a distance which made their regular attendance for follow-up very difficult, and some mothers withdrew their babies for domestic reasons. Thus, at the end of the trial we were left for analysis a selected group of babies who had no serious illness and whose mothers felt sufficiently concerned for their welfare to bring them for examination each month. In this selected series the only evidence consistent with folate deficiency in the control group was the significantly higher mean $\mathrm{MCV}$ at 6 months. This could be due to

TABLE III

Comparison of mean levels of serum folate and red cell folate for the treated and placebo groups

\begin{tabular}{|c|c|c|c|c|c|c|}
\hline \multirow{2}{*}{ Variable } & \multicolumn{3}{|c|}{ Treated } & \multicolumn{3}{|c|}{ Placebo } \\
\hline & No. & Mean & Range & No. & Mean & Range \\
\hline $\begin{array}{l}\text { At } 2 w k \\
\text { Serum folate }(\mathrm{ng} / \mathrm{ml}) \\
\text { Red cell folate }(\mathrm{ng} / \mathrm{ml}) \\
\text { At } 4 \text { mth } \\
\text { Serum folate }(\mathrm{ng} / \mathrm{ml}) \\
\text { Red cell folate }(\mathrm{ng} / \mathrm{ml}) \\
\text { At } 6 \text { mth } \\
\text { Serum folate }(\mathrm{ng} / \mathrm{ml}) \\
\text { Red cell folate }(\mathrm{ng} / \mathrm{ml})\end{array}$ & $\begin{array}{l}26 \\
29 \\
20 \\
21 \\
\\
24 \\
24\end{array}$ & $\begin{array}{c}4 \cdot 7 \\
638 \\
11 \cdot 1 \\
758 \\
10 \cdot 4 \\
774\end{array}$ & $\begin{array}{l}(3 \cdot 8-5 \cdot 9) \\
(552-738) \\
(8 \cdot 4-14 \cdot 6) \\
(632-909) \\
(7 \cdot 7-14 \cdot 0) \\
(634-946)\end{array}$ & $\begin{array}{l}29 \\
32 \\
29 \\
29 \\
26 \\
26\end{array}$ & $\begin{array}{c}6 \cdot 7 \\
695 \\
5 \cdot 9 \\
472 \\
\quad 7 \cdot 3 \\
590\end{array}$ & $\begin{array}{l}(5 \cdot 9-8 \cdot 8) \\
(597-809) \\
\\
(4 \cdot 8-7 \cdot 2) \\
(388-573) \\
\\
(5 \cdot 9-8 \cdot 9) \\
(470-715)\end{array}$ \\
\hline
\end{tabular}

Note: Mean and range obtained following $\log _{10}$ transformation. Range stated is mean $\pm 2 S E$. 
macrocytes formed between 2 weeks and 4 months remaining in the circulation. However, the mean serum and red cell folate of the untreated group were well within the accepted normal range and the $\mathrm{Hb}$ levels were similar to those in the treated group, at both 4 months and 6 months.

Infections and gastrointestinal disturbances are factors in causing folate deficiency in low birthweight babies and conversely folate deficiency might be expected to predispose to infections, though no proof of this has been found. None of the infections occurring in the infants of this trial was severe. They were more frequent in the control group; the difference from the treated group did not, however, reach a level of significance. Further investigation with larger numbers might provide further evidence on this matter.

From an oral dose of $50 \mu \mathrm{g}$ folic acid adequate absorption occurred, since at 4 months and 6 months both red cell and serum levels were significantly higher in the treated than in the control group, confirming the findings of Samuel, Burland, and Simpson (1973) that both pteroylmonoglutamic acid and pteroylpolyglutamate are absorbed by newborn infants of low birthweight. In our control group the levels were within the usually accepted normal range and gave us no reason to believe that the folate supplements received by the treated group were necessary. Clearly, the infants in our series for analysis were receiving adequate amounts of folic acid in their normal diet and did not require supplements. Folate supplements might, however, be necessary in premature infants if dietary intake is deficient or if the infant is suffering from an infection or haemolytic anaemia.

We thank Mr. J. Baker, Area Pharmacist, for his help and advice. The work was supported by a research grant from the Birmingham Regional Hospital Board.

\section{REFERENCES}

Burland, W. L., Simpson, K., and Lord, J. (1971). Response of low birthweight infants to treatment with folic acid. Archives of Disease in Childhood, 46, 189.

Chanarin, I. (1969). Megaloblastic Anaemias, p. 751. Blackwell Scientific Publications, Oxford and Edinburgh.

Davis, R. E., Nicol, D. J., and Kelly, A. (1970). An automated method for the measurement of folate activity. Fournal of Clinical Pathology, 23, 47.

Hoffbrand, A. V. (1970). Folate deficiency in premature infants. Archives of Disease in Childhood, 45, 441.

MacIver, J. E. (1962). Megaloblastic anaemias. Pediatric Clinics of North America, 9, 727.

Roberts, P. M. M., Arrowsmith, D. E., Lloyd, A. V. C., and Monk-Jones, M. E. (1972). Effect of folic acid treatment on premature infants. Archives of Disease in Childhood, 47, 631.

Roberts, P. M., Arrowsmith, D. E., Rau, S. M., and Monk-Jones, M. E. (1969). Folate state of premature infants. Archives of Disease in Childhood, 44, 637.

Samuel, P. D., Burland, W. L., and Simpson, K. (1973). Response to oral administration of pteroylmonoglutamic acid or pteroylpolyglutamate in newborn infants of low birth weight. British Fournal of Nutrition, 3J, 165.

Correspondence to Dr. N. K. Shinton, Department of Heenatology, Coventry and Warwickshire Hospital Stoney Stanton Road, Coventry CV1 4FH. 